\title{
Pengaruh Tingkat Pengetahuan dan Sikap Ibu terhadap Penyakit Kecacingan Pada Balita
}

\author{
Rahayu Lubis ${ }^{1}$, Merina Panggabean ${ }^{2}$, Hemma Yulfi ${ }^{2}$ \\ ${ }^{1}$ Departemen Epidemiologi, Fakultas Kesehatan Masyarakat, Universitas Sumatera Utara \\ ${ }^{2}$ Departemen Parasitologi, Fakultas Kedokteran, Universitas Sumatera Utara
}

Info Artikel:Diterima Januari 2018 ; Disetujui Februari 2018 ; Publikasi April 2018

\begin{abstract}
ABSTRAK
Latar belakang: Kejadian kecacingan pada balita di Indonesia masih tinggi. Untuk mengurangi kejadian kecacingan balitamemerlukan upaya terintegrasi seperti peningkatan perilaku sehat. Hal ini dapat diwujudkan dengan memberikan pengetahuan pada masyarakat terutama ibu yang mempunyai balita. Oleh karena itu perlu dilakukan penelitian tentang pengetahuan dan sikap ibu yang mempunyai anak balita yang dibawa ke posyandu untuk pencegahan penyakit kecacingan pada balita

Metode: Ini adalah penelitian quasi experiment,pre and post test design. Populasi adalah ibu yang mempunyai anak balita yang datang ke posyandu Sentosa di Kota Medan tahun 2016. Sampel adalah ibu yang bersedia memeriksakan tinja anak balitanya. Sampel diambil secara purposif yaitu sebanyak 50 orang. Intervensi yang diberikan berupa penyuluhan (ceramah dan video). Pengumpulan data menggunakan kuesioner dan catatan medik Puskesmas Sentosa Baru. Analisis data secara univariat, bivariat menggunakan analisis uji chi-square.

Hasil: Total dari 50ibu yang mempunyai anak balita sebagian besar pada kelompok umur 20-30 tahun, berpendidikan SMP, bekerja sebagai ibu rumah tangga dan mempunyai anak 1-2 orang. Ada peningkatan pengetahuan dan sikap yang baik sebesar $43 \%$ dan $52 \%$ sesudah di berikan intervensi. Ada pengaruh tingkat pengetahuan ibu terhadap infeksi kecacingan pada balita $(R R=1,96 ; 95 \% \mathrm{CI}: 1,12-4,15 ; \mathrm{p}=0,002)$. Ada pengaruh sikap ibu terhadap infeksi kecacingan pada balita $(\mathrm{RR}=2,46 ; 95 \% \mathrm{CI}: 1,46-5,62 ; \mathrm{p}=0,001)$.

Simpulan: Infeksi kecacingan pada anak balita dipengaruhi oleh pengetahuan dan sikap ibu. Untuk menjaga kesehatan anaknya perlu menjaga kebersihan diri dan lingkungan sertamelakukan pemeriksaan kesehatan secara periodik, penyuluhan kesehatan secara rutin perlu diberikan pada ibu yang datang ke posyandu
\end{abstract}

Kata kunci: Kecacingan; Pengetahuan ibu; Sikap; Balita; Posyandu Sentosa Medan

\section{ABSTRACT}

Title: The Influence of Maternal Knowledgeand Attitude Against Soil Transmitted Helminths Infections in Children Lessthan Five Years Old

Background:The incidenceof helminthes infection in children less than five years old is still high in Indonesia. To reduce the incidence of helminthes infectionneeds an integrated effort such as the improvement of healthy behavior. This can be realized by providing knowledge to the community, especially mothers with children under five years. Therefore it is necessary to do research on knowledge and attitude of mother who have children under five who brought to posyandu for prevention of diseases of helminthes infection in children less than five years old

Method:This is a quasi-experimental study pre and post-test design. The population is mothers who have children less than five years old who come to posyandu Sentosa in Medan City in 2016. The sample is the mother who is willing to check the feces of her children. The sample was taken purposively as many as 50 people. Data collection was using structural questioners before and after intervention (lectures and video) about helminthesinfection.Data medical records from Puskesmas Sentosa Baru Medan. Data analysis univariate and bivariate using chi-square test. 
Result: $A$ total of 50 mothers with children less than five years old are mostly in the age group 20-30 year, junior high school educated, work as housewives and have 1-2 children. There is an increase in knowledge and good attitude by $43 \%$ and $52 \%$ after intervention.Mothers with not good knowledge and not good attitude were significantly influence intensity of helminthesinfection in children $(R R=1.96 ; 95 \% C I 1.12-4.15, p=0.002)$ and $(R R=2.46,95 \%$ CI 1.46-5.62, $p=0.001)$ respectively.

Conclusion: There was influence of maternal knowledge and attitude against helminthes infection in children less than five years old. Awareness in protection of personal and environment hygiene, periodic medical checkup should be done for improve health children. Health counseling routinely needs to be given to mothers who come to posyandu

Keywords: Helminths; Maternal knowledge; Attitude; Children; Posyandu Sentosa Medan

\section{PENDAHULUAN}

Penyakit kecacingan masih banyak terjadi di Indonesia terutama pada balita. ${ }^{1}$ Salah satu penyakit kecacingan yang sering terjadi adalah penyakit cacing yang ditularkan melalui tanah atau disebut juga Soil Transmitted Helminth (STH). Infeksi kecacingan ini

bersifat kronis tanpa menimbulkan gejala klinis yang jelas dan dampak yang ditimbulkannya baru terlihat dalam jangka panjang seperti kekurangan gizi, gangguan tumbuh kembang dan gangguan kognitif anak, ${ }^{2}$ danjuga mengakibatkan menurunnya kondisi kesehatan, kecerdasan dan produktivitas anak. ${ }^{3}$

Lima spesies cacing yang termasuk dalam kelompok Soil Transmitted Helminthyang masih menjadi masalah kesehatan, yaitu Ascaris lumbricoides, Trichuris trichiura, Strongyloides stercoralis dan cacing tambang (Necator americanus dan Ancylostoma $s p) .{ }^{4}$ Spesies cacing tambang yang banyak ditemukan di Indonesia ialah Necator americanus. ${ }^{1}$ Gejala klinis yang ditimbulkan dapat berupa ground itch,creeping eruption, pneumonitis, abdominal discomfort, hipoproteinemia dan anemia defisiensi besi. ${ }^{5}$

Prevalensi infeksi kecacingan di Indonesia masih relatif tinggi, yaitu sebesar $28,12 \%$, terutama pada golongan penduduk dengan sosio-ekonomi rendah. ${ }^{1}$ Kelompok ini mempunyai risiko tinggi terjangkit penyakit kecacingan karena kurang menjaga higiene dan sanitasi lingkungan tempat tinggalnya.Berbagai upaya terus dilakukan untuk mengurangi infeksi kecacingan dengan mempromosikan perilaku hidup sehat dan sanitasi yang bersih.Program minum obat cacing saja tidak akan berhasil bila tidak diikuti dengan upaya terintegrasi seperti adanya peningkatan kondisi lingkungan yang sehat dan mengubah perilaku orang yang berisiko terkena kecacingan. ${ }^{6}$ Kelompok resiko tinggi terkena penyakit kecacingan adalah anak balita karena suka memasukkan sesuatu kedalam mulutnya dan bermain ditanah tanpa alas kaki. ${ }^{7}$ Perawatan balita tergantung dari ibunya, oleh karena itu ibu yang mempunyai anak balita harus menjaga kebersihan balitanya. Hal ini dapat diwujudkan dengan memberikan pengetahuan dan sosialisasi pada masyarakat terutama ibu yang mempunyai balita mengenai perilaku hidup bersih dan sehat. Dengan pemberian pengetahuan secara komprehensif diharapkan akan dapat mengubah perilaku ibu. Dari data diatas terlihatpentingnya memberikan intervensi pengetahuan pada ibu yang mempunyai anak balita, oleh karena itu peneliti ingin menganalisis pengetahuan dan sikap ibu yang mempunyai anak balita untuk pencegahan penyakit kecacingan pada balita.

Penyakit kecacingan termasuk dalam sepuluh besar penyakit yang ada di puskesmas Sentosa Kota Medan. ${ }^{8}$ Wilayah kerja Puskesmas Sentosa termasuk daerah perkotaan. Sedangkan penyakit kecacingan biasanya banyak terjadi di daerah perkebunan maka ada faktor lain seperti perilaku ibu yang berperan terhadap kejadian penyakit kecacingan tersebut. Oleh karena itu perlu dilakukan penelitian untuk mengetahui pengaruh pengetahuan dan sikap ibu yang mempunyai anak balita terhadap penyakit kecacingan melalui intervensi penyuluhan.

\section{MATERI DAN METODE}

Jenis Penelitian ini adalah penelitian quasi eksperimentdengan pre and post test design yaitu penelitian dilakukan dengan melihat perbedaan pengetahuan dan sikap ibu sebelum dan sesudah diberikan intervensi penyuluhan tentang penyakit kecacingan terhadap kejadian penyakit kecacingan pada balita. Penelitian ini dilakukan di wilayah kerja Puskesmas Sentosa Kota Medan pada bulan Mei sampai November tahun 2016.

Populasi pada penelitian ini adalah ibu yang mempunyai anak balita yang datang ke posyandu Sentosa di Kota Medan. Sampel adalah sebagian dari populasi yang bersedia untuk memeriksakan tinja anak balitanya. Penentuan besar sampel dalam penelitian ini diambil secara purposive yaitu sebanyak 50 orang (terdiri dari 50 orang ibu dan 50 sampel tinja balita untuk diperiksa).

Cara pengumpulan data primer dilakukan dengan wawancara menggunakan kuesioner terstruktur yang diberikan sebelum dan sesudah intervensi. Intervensi yang diberikan berupa penyuluhan (ceramah dan video) tentang penyakit kecacingan diberikan satu kali pertemuan. Kunjungan ke rumah responden untuk wawancara dan observasi kegiatan ibu dilakukan setelah 2 hari dari pemberian intervensi. Kuesioner pengetahuan berisi 15 pertanyaan dan kuesioner sikap berisi 10 pertanyaan.Pertanyaan di dalam kuesioner ini 
telah di uji validitas dan reliabilitasnya dan setiap pertanyaan mempunyai nilai tertentu.Tingkat pengetahuan dan sikap dibagi menjadi 2 kategori yaitu baik dan tidak baik. Seorang responden akan dikatakan masuk kategori baik bila mempunyai nilai lebih $75 \%$ dari total nilai dan kategori tidak baik bila memperoleh nilai kurang atau sama dengan 75\%.Pengamatan terhadap sikap ibu dilakukan sebagai cross cek dari wawancara yang meliputi penggunaan air bersih, penggunaan sabun saat mencuci tangan dan kaki, dan kondisi lingkungan sekitar rumah. Pemeriksaan tinja balita dari ibu yang datang ke posyandu sentosa dilakukan dengan metode Kato-Katz. Tempat pemeriksaan nya di laboratorium parasitologi Fakultas Kedokteran Universitas Sumatera Utara. Data sekunder diperoleh dari rekam medic pasien dan profil Puskesmas Sentosa Kota Medan.

Data yang diperoleh dari wawancara dan hasil pemeriksaan tinja kemudian dilakukan pengolahan mulai dengan pemeriksaan kelengkapan data, penyuting, memberi kode, entri data dan tabulasi. Analisa univariat digunakan untuk menjelaskan distribusi frekuensi masing-masing variabel yang diteliti dan disajikan dalam tabel. Analisa bivariat menggunakan uji Chi-square digunakan untuk mengetahui pengaruh tingkat pengetahuan dan sikap ibu terhadap infeksi kecacingan pada balita. Penelitian ini sudah mendapat ijin dari KomisiEtikPenelitian Kesehatan Fakultas Keperawatan Universitas Sumatera Utara dengan nomor surat 1049/IX/SP/2016.

\section{HASIL DAN PEMBAHASAN}

Karakteristik sosiodemografik responden dapat dillihat pada Tabel 1.Jumlah ibu yang datang ke posyandu Sentosa dan bersedia sebagai responden penelitian ada 50 orang. Ibu yang mempunyai balita sebagian besar pada kelompok umur 31-40 tahun (40\%), suku Jawa (46\%), dengan tingkat pendidikan SMP (58\%), pekerjaan terbanyak adalah ibu rumah tangga $(76 \%)$, dan mempunyai anak $1-2$ orang $(62 \%)$.

\begin{tabular}{lcc}
\multicolumn{2}{l}{ Tabel 1. Karakteristik sosiodemografik responden } \\
\hline Variabel & f & $\mathbf{\%}$ \\
\hline Umur (tahun) & 16 & 32 \\
$20-30$ & 20 & 40 \\
$31-40$ & 14 & 38 \\
$>40$ & & \\
Suku/ras & 23 & 46 \\
$\quad$ Jawa & 17 & 34 \\
$\quad$ Mandailing/Batak & 10 & 20 \\
$\quad$ Lain-lain & & \\
Pendididikan & 11 & 22 \\
$\quad$ SD & 29 & 58 \\
$\quad$ SMP & 10 & 20 \\
$\quad$ SMA/PT & & \\
Pekerjaan & 38 & 76 \\
IRT & 12 & 24 \\
$\quad$ Lain-lain & & \\
Jumlah anak & 31 & 62 \\
1-2 & 13 & 26 \\
3-4 & 6 & 12 \\
$>4$ & & \\
\hline
\end{tabular}

Tabel 2. Distribusi frekuensi jawaban pengetahuan responden

\begin{tabular}{|c|c|c|c|c|}
\hline \multirow[b]{2}{*}{ Pertanyaan } & \multicolumn{2}{|c|}{ Sebelum } & \multicolumn{2}{|c|}{ Sesudah } \\
\hline & $\begin{array}{l}\text { Benar } \\
\text { f (\%) }\end{array}$ & $\begin{array}{l}\text { Salah } \\
\text { f (\%) }\end{array}$ & $\begin{array}{l}\text { Benar } \\
\text { f (\%) }\end{array}$ & $\begin{array}{l}\text { Salah } \\
\text { f (\%) }\end{array}$ \\
\hline Apa arti penyakit kecacingan & $30(60)$ & $20(40)$ & $48(96)$ & $2(4)$ \\
\hline Apa tanda dan gejala penyakit kecacingan & $26(52)$ & $24(48)$ & $45(90)$ & $5(10)$ \\
\hline Apa jenis-jenis cacing yang diketahui & $22(44)$ & $28(56)$ & $42(84)$ & $8(16)$ \\
\hline Bagaimana cara masuk cacing ke dalam tubuh manusia & $20(40)$ & $30(60)$ & $41(82)$ & $9(18)$ \\
\hline Bagaimana cara keluar cacing dari dalam tubuh manusia & $27(54)$ & $23(46)$ & $49(98)$ & $1(2)$ \\
\hline Dengan cara apa penularan cacing & $23(46)$ & $27(54)$ & $47(94)$ & $3(6)$ \\
\hline Dimana telur cacing dapat hidup & $20(40)$ & $30(60)$ & $45(90)$ & $5(10)$ \\
\hline Bagaimana kita tahu orang kena penyakit kecacingan & $25(50)$ & $25(50)$ & $48(96)$ & $2(4)$ \\
\hline Pemeriksaan apa yang perlu dilakukan & $20(40)$ & $30(60)$ & $49(98)$ & $1(2)$ \\
\hline Apaobat untuk penyakit kecacingan & $30(60)$ & $20(40)$ & $49(98)$ & $1(2)$ \\
\hline Berapa kali obat itu diberikan per tahun & $35(70)$ & $15(30)$ & $49(98)$ & $1(2)$ \\
\hline Kapan perlu memotong kuku & $31(62)$ & $19(38)$ & $48(96)$ & $2(4)$ \\
\hline Kapan sebaiknya mencuci tangan & $29(58)$ & $21(32)$ & $47(94)$ & $3(6)$ \\
\hline Apakah mencuci tangan dengan sabun setelah BAB perlu & $27(54)$ & $23(46)$ & $49(98)$ & $1(2)$ \\
\hline Apakah perlu pakai alas kaki bila berjalan di tanah & $25(50)$ & $25(50)$ & $48(96)$ & $2(4)$ \\
\hline
\end{tabular}


Tingkat pengetahuan responden tentang penyakit kecacingan dan cara pencegahannya di ukur dengan menggunakan kuesioner yang berisi beberapa pertanyaan. Pertanyaan dalam kuesioner yang diberikan dapat mewakili pengetahuan responden tentang penyakit kecacingan dan cara pencegahannya. Data lengkap mengenai distribusi frekuensi jawaban responden dapat dilihat pada Tabel 2.

Pertanyaan pengetahuan yang paling banyak di jawab dengan benar sesudah dilakukan intervensi adalah pertanyaan nomor 5 (Bagaimana cara keluar cacing dari dalam tubuh manusia), 9 (Pemeriksaan apa yang perlu dilakukan), 10(Apaobat untuk penyakit kecacingan), 11 (Berapa kali obat itu diberikan per tahun) dan 14(Apakah mencuci tangan dengan sabun setelah BAB perlu) yaitu sebesar 98\%. Sementara pertanyaan pengetahuan yang paling banyak di jawab salah sebelum dilakukan intervensi adalah nomor 4 (Bagaimana cara masuk cacing ke dalam tubuh manusia), 7 (Dimana saja telur cacing dapat hidup) dan 9 (Pemeriksaan apa yang diperlukan untuk mengetahui penyakit kecacingan) yaitu sebesar $60 \%$. Tingkat pengetahuan dalam penelitian ini dibagi menjadi 2 kategori yaitu pengetahuan baik dan tidak baik. Sebelum di berikan intervensi ada 58\% responden dengan pengetahuan tidak baik dan $42 \%$ berpengetahuan baik.

Menurut hasil penelitian Karmilla tahun 2012 di Pontianak menyatakan bahwa sebahagian besar respondennya berpendidikan SMP dan mempunyai praktek personal hygiene yang kurang baik. ${ }^{9}$ Hal ini sesuai dengan kondisi responden penelitian ini sebelum diberi intervensi penyuluhan dimana sebagian besar responden berpendidikan SMP dan berpengetahuan tidak baik. Setelah diberi intervensi tingkat pengetahuan dengan kategori baik meningkat menjadi $85 \%$, berarti ada penambahan tingkat pengetahuan dengan kategori baik sebelum dan sesudah diberi intervensi penyuluhan sebesar 43\%.Hal ini dapat dilihat pada Tabel 4.

Pengukuran sikap responden tentang cara pencegahan penyakit kecacingan berisi pertanyaan yang dapat mewakili sikap responden tentang cara pencegahan penyakit kecacingan. Data lengkap mengenai distribusi frekuensi jawaban responden pada variabel sikap dapat dilihat pada Tabel 3.Pernyataan sikap yang paling disetujui oleh responden sebelum diberi intervensi adalah pernyataan nomor 5 (BAB anak balita sembarangan tidak menularkan kecacingan) yaitu 54\%. Pernyataan sikap yang paling banyak dijawab dengan tidak setuju sebelum intervensi adalah nomor 1 (memotong kuku dapat mencegah kecacingan) dan 3 (kebersihan lingkungan dapat mencegah kecacingan) yaitu $60 \%$. Setelah dilakukan intervensi maka pernyataan sikap yang paling disetujui oleh responden adalah pernyataan nomor 1(memotong kuku dapat mencegah kecacingan) dan 6 (obat cacing dapat diberikan di sekolah) yaitu $94 \%$ dan pernyataan sikap yang paling banyak dijawab dengan tidak setuju adalah pernyataan nomor 5 (BAB anak balita sembarangan tidak menularkan kecacingan) dan 8 (tidak perlu memakai alas kaki berjalan di tanah sekitar rumah)yaitu 96\%.Penilaian sikap dalam penelitian ini dibedakan menjadi 2 kategori yaitu sikap baik dan sikap tidak baik. Sikap responden sebelum diberi intervensi dengan kategori baik adalah 36\%. Setelah diberi intervensi sikap responden dengan kategori baik meningkat menjadi $88 \%$, berarti ada penambahan sikap responden dengan kategori baik sebelum dan sesudah diberi intervensi penyuluhan yaitu sebesar $52 \%$. Hasil penelitian ini sesuai dengan penelitian Fitri tahun 2012 di Tapanuli Selatan yang menyatakan bahwa kebersihan kuku, penggunaan alas kaki, kebiasaan cuci tangan memberikan pengaruh bermakna terhadap kejadian infeksi kecacingan. ${ }^{10}$

Tabel 3. Distribusi frekuensi jawaban sikap responden

\begin{tabular}{|c|c|c|c|c|c|c|}
\hline \multirow[t]{2}{*}{ Pertanyaan } & \multicolumn{3}{|c|}{ Sebelum } & \multicolumn{3}{|c|}{ Sesudah } \\
\hline & $\begin{array}{c}\text { SS } \\
\text { f }(\%)\end{array}$ & $\begin{array}{c}\mathrm{KS} \\
\mathbf{f}(\%)\end{array}$ & $\begin{array}{c}\text { TS } \\
\mathbf{f}(\%)\end{array}$ & $\begin{array}{c}\text { SS } \\
\text { f (\%) }\end{array}$ & $\begin{array}{c}\mathrm{KS} \\
\mathbf{f}(\%)\end{array}$ & $\begin{array}{c}\text { TS } \\
\text { f (\%) }\end{array}$ \\
\hline Memotong kuku dapat mencegah kecacingan & $8(16)$ & $12(24)$ & $30(60)$ & $47(94)$ & $2(4)$ & $1(2)$ \\
\hline Kebersihan rumah dapat mencegah kecacingan & $9(18)$ & $12(24)$ & $29(58)$ & $45(90)$ & $3(6)$ & $2(4)$ \\
\hline lingkungan bersih dapat mencegah kecacingan & $9(18)$ & $11(22)$ & $30(60)$ & $42(84)$ & $6(12)$ & $2(4)$ \\
\hline $\begin{array}{l}\text { Jajan sembarangan tidak menyebabkan } \\
\text { kecacingan }\end{array}$ & $25(50)$ & $12(24)$ & $13(26)$ & $3(6)$ & $4(8)$ & $43(86)$ \\
\hline $\begin{array}{l}\text { BAB anak balita sembarangan tidak } \\
\text { menularkan kecacingan }\end{array}$ & $27(54)$ & $20(40)$ & $3(6)$ & $1(2)$ & $1(2)$ & $48(96)$ \\
\hline Obat cacing dapat diberikan di sekolah & $20(40)$ & $17(34)$ & $13(26)$ & 47 (94) & $2(4)$ & $1(2)$ \\
\hline $\begin{array}{l}\text { Kecacingan tidak berbahaya karena banyak } \\
\text { diderita anak-anak }\end{array}$ & $25(50)$ & $13(26)$ & $12(24)$ & $1(2)$ & $4(8)$ & $45(90)$ \\
\hline $\begin{array}{l}\text { Tidak perlu memakai alas kaki berjalan di } \\
\text { tanah sekitar rumah }\end{array}$ & $26(52)$ & $14(28)$ & $10(20)$ & $2(4)$ & $2(4)$ & $48(96)$ \\
\hline $\begin{array}{l}\text { Cuci tangan dengan air saja setelah BAB sudah } \\
\text { cukup }\end{array}$ & $20(40)$ & $18(36)$ & $12(24)$ & $1(2)$ & $2(2)$ & 47 (94) \\
\hline $\begin{array}{l}\text { Pencegahan kecacingan adalah tanggung } \\
\text { jawab petugas kesehatan saja }\end{array}$ & $30(60)$ & $13(26)$ & $7(14)$ & $2(4)$ & $2(4)$ & $46(92)$ \\
\hline
\end{tabular}


Tabel 4. Distribusi tingkat pengetahuan dan sikap responden

\begin{tabular}{lcccc}
\hline & \multicolumn{2}{c}{ Sebelum intervensi } & \multicolumn{2}{c}{ Sesudah intervensi } \\
\cline { 2 - 5 } & f & $\mathbf{\%}$ & f & $\%$ \\
\hline Pengetahuan & 21 & 42 & 43 & 85 \\
$\quad$ Baik & 29 & 58 & 7 & 15 \\
$\quad$ Tidak Baik & & & & \\
Sikap & 18 & 36 & 44 & 88 \\
$\quad$ Baik & 42 & 84 & 6 & 12 \\
$\quad$ Tidak Baik & 50 & 100 & 50 & 100 \\
\hline Total & & & & \\
\hline
\end{tabular}

Tabel 5. Hasil pemeriksaan tinja balita

\begin{tabular}{lll}
\hline Infeksi Soil Transmitted Helminth & Frekuensi & Persentase \\
\hline Positif & 23 & $46 \%$ \\
Negatif & 27 & $54 \%$ \\
\hline Total & 50 & $100 \%$ \\
\hline
\end{tabular}

Tabel 6. Jenis infeksi kecacingan balita

\begin{tabular}{lll}
\hline Infeksi Soil Transmitted Helminth & Frekuensi & Persentase \\
\hline Trichiuris trichiura & 5 & $21,7 \%$ \\
Ascaris lumbricoides & 2 & $8,7 \%$ \\
Trichiuris trichiura + Ascaris lumbricoides & 16 & $69,6 \%$ \\
\hline Total & 23 & $100 \%$ \\
\hline
\end{tabular}

Dari hasil pemeriksaan SHTpada table 5, sebanyak 50 sampel tinja yang di dapat diketahui bahwa ada 23 $(46 \%)$ balita yang terinfeksi STH. Sedangkan 27 (54\%) balita lainnya tidak terinfeksi STH.

Rincian dari balita yang terinfeksi STHadalah balita yang terinfeksi Trichiuris trichiura ada 5 (21,7\%), infeksi Ascaris lumbricoides ada 2 (8,7\%) dan infeksi campuran (Trichiuris trichiura + Ascaris lumbricoides) ada $16(69,6 \%)$, dilihat pada Tabel6.

Klasifikasi infeksi STH ditentukan berdasarkan kriteria WHO dibagi tiga kategori yaitu ringan, sedang dan berat.Bila terinfeksi campuran (Trichiuris trichiura + Ascaris lumbricoides) ditentukan intensitas infeksinya berdasarkan intensitas terberat dari masingmasing infeksi. ${ }^{11}$ Infeksi campuran cacing Ascarislumbricoidesdan Trichuristrichiurasering terjadi dan dipengaruhi oleh keadaan tanah dan curah hujan. Telur Ascarislumbricoidesdan Trichuristrichiuratumbuh lebih baik di tanah liat karena kelembaban tanah seperti ini sangat cocok bagi pertumbuhannya. Selain itu tanah juga banyak mengandung larva cacing lain seperti Wucherecia bancrofti terutama tanah yang becek dan di dasar perairan tawar dan laut yang bisa menyebabkan penyakit filariasis ${ }^{12}$. Manusia dapat tertular kecacinganmelalui kulit yang utuh, mukosa, makanan yang terkontaminasi dengan tanah dan kotoran manusia.Oleh karena itu, hindari anak balita berjalan di tanah tanpa alas kaki dan segera mencuci tangan anak balita bila terkontaminasi tanah.
Faktor lain yang mempengaruhi infeksi kecacinganadalah perilaku buang air besar tidak di jamban yang menyebabkan pencemaran tanah oleh feses yang mengandung telurcacing. ${ }^{13}$ Pencemaran tanah ini terjadi di halaman rumah, dibawah pohon dan di tempat-tempat pembuangan sampah, dimana sering dijadikan tempat bermain oleh anak balita.

Pengetahuan orang tua merupakan faktor risiko dominan terjadinya penyakit pada anak. Anak yang memiliki orang tua dengan pengetahuan kurang baik mempunyai risiko lebih besar untuk menderita penyakit. ${ }^{14}$ Pengaruh tingkat pengetahuan dan sikap ibu terhadap infeksi kecacingan pada balita dapat ditunjukkan pada Tabel 7. Ibu yang mempunyai pengetahuan tidak baik dan mempunyai anak balita yang terinfeksi STH ada $(65,5 \%)$. Hasil uji chi-square di dapat $p$-value 0,002 artinya ada pengaruh tingkat pengetahuan ibu dengan infeksi kecacingan pada balita. Ukuran risiko pada penelitian ini adalah relative risk (RR) didapat 1,96 artinya ibu yang mempunyai pengetahuan tidak baik berpengaruh terhadap infeksi STH pada balita sebesar 1,96 kali. Hal ini sesuai dengan penelitian Chadijah tahun 2013 yang menemukan dari 90 responden ada 33,67\% memiliki tingkat pengetahuan tidak baik dan terinfeksi kecacingan. ${ }^{15}$ Ini sesuai juga dengan penelitian Tumanggor tahun 2008 yang menunjukkan ada hubungan antara tingkat pengetahuan dengan infeksi kecacingan. ${ }^{6}$ 
Tabel 7. Pengaruh tingkat pengetahuan dan sikap ibu terhadap infeksi kecacingan balita

\begin{tabular}{llllll}
\hline & \multicolumn{2}{c}{ Infeksi Kecacingan } & Jumlah & p-value & RR ((5\% CI) \\
\cline { 2 - 3 } & $\begin{array}{c}\text { Positif } \\
\text { f (\%) }\end{array}$ & $\begin{array}{c}\text { Negatif } \\
\mathbf{f}(\%)\end{array}$ & f (\%) & & \\
\hline $\begin{array}{l}\text { Pengetahuan } \\
\quad \text { Tidak Baik }\end{array}$ & $19(65,5 \%)$ & $10(34,5 \%)$ & $29(100 \%)$ & 0,002 & $1,96(1,12-4,15)$ \\
$\quad$ Baik & $7(33,3 \%)$ & $14(66,6)$ & $21(100 \%)$ & & \\
$\begin{array}{l}\text { Sikap } \\
\quad \text { Tidak Baik }\end{array}$ & $20(68,9 \%)$ & $9(31,1 \%)$ & $29(100 \%)$ & 0,001 & $2,46(1,45-5,62)$ \\
$\quad$ Baik & $6(28,6 \%)$ & $15(71,4)$ & $21(100 \%)$ & & \\
\hline
\end{tabular}

Hasil kuesioner tentang sikap responden sebelum di intervensiada $60 \%$ jawaban yang tidak setuju tentang kebersihan lingkungan dapat mencegah kecacingan pada balita. Hal ini sejalan dengan penelitian Salbiah tahun 2008 dimana responden tidak yakin bahwa kebersihan lingkungan dapat mencegah kecacingan. ${ }^{16} \mathrm{Ibu}$ yang mempunyai sikap tidak baik dan mempunyai anak balita yang terinfeksi STH ada $(68,9 \%)$. Hasil uji chi-squaretentang pengaruh sikap responden terhadap infeksi kecacingandidapat $p$-value 0,001 artinya ada pengaruh sikap ibu dengan infeksi kecacingan pada balita.Nilai Relative risk didapat 2,46 artinya ibu yang mempunyai sikap tidak baik berpengaruh terhadap infeksi STH pada balita sebesar 2,46 kali. Sikap diturunkan dari pengetahuan dengan demikian untuk menentukan sikap harus didasari oleh pengetahuan responden, jadi pengetahuan yang tidak baik sejalan dengan sikap yang tidak baik pula demikian juga sebaliknya.

\section{SIMPULAN}

Karakteristik sosiodemografik, ibu yang mempunyai anak balita yang datang ke posyandu Sentosa Medan mayoritas adalah kelompok umur 2030 tahun, berpendidikan SMP, bekerja sebagai ibu rumah tangga dan mempunyai anak 1-2 orang. Ada peningkatan pengetahuan dan sikap yang baik sesudah di berikan intervensi penyuluhan dan video tentang penyakit kecacingan.Ada pengaruh tingkat pengetahuan dan sikap ibu dengan infeksi kecacingan pada balita. Ibu yang mempunyai pengetahuan tidak baik berpengaruh terhadap infeksi kecacingan pada balita sebesar 1,96 kali dan ibu yang mempunyai sikap tidak baik berpengaruh terhadap infeksi kecacingan pada balita sebesar 2,46 kali.

\section{SARAN}

Perlu penyuluhan secara terus-menerus kepada ibu yang mempunyai balita yang datang ke posyandu. Perlu koordinasi lintas sektor untuk memperlancar proses penyuluhan pada ibu yang mempunyai balita yang datang ke posyandu dan dapat dilakukan secara rutin

\section{UCAPAN TERIMA KASIH}

Penelitian ini mendapat dukungan dana BPPTN Universitas Sumatera Utara Tahun 2016.

\section{DAFTAR PUSTAKA}

1. Kemenkes RI. Profil Kesehatan Indonesia. 2013
2. Kurniawan A. Infeksi Parasit: Dulu dan Masa Kini. Majalah Kedokteran Indonesia, 2010;60(11):48788

3. Soedarto. Parasitologi Klinik. AirlanggaUniversity Press.2008, Hal. 71-96.

4. Behrman, Kligman, Arvin dan Nelson, Ilmu Kesehatan Anak, Penerbit Buku Kedokteran (EGC), Jakarta.2000

5. Natadisastra D dan Agoes R. Parasit Kedokteran di Tinjau dari Organ Tubuh yang Diserang. EGC. 2009,Hal: 69-86.

6. Tumanggor, A.H. Hubungan Perilaku dan Higiene Siswa SD Negri 030375 dengan Infeksi Kecacingan di Desa Juma Teguh Kecamatan Siempat Nempu Kabupaten Dairi. Repository USU.2008

7. Widjana DP and Sutisna P. Prevalence of SoilTransmtted Helminth Infection In The Rural Pupulation Of Bali, Indonesia. Southeast Asian J Trop Med Public Health, September 2000; 31(3): 454-459

8. Departemen kesehatan. Profil Dinas Kesehatan Kota Medan. 2015

9. Kamilla L, Suhartono, Nur Endah W. Hubungan Praktek Personal HygieneIbu dan Kondisi Sanitasi Lingkungan Rumah Dengan Kejadian Diare di Puskesmas Kampung Dalam Kecamatan Pontianak Timur. Jurnal Kesehatan Lingkungan Indonesia, Oktober 2012;2 (2): 138-143

10. Fitri, J., Saam, Z., Hamidy, MY. Analisis Faktorfaktor Risiko Infeksi Kecacingan Murid Sekolah Dasar di Kecamatan Angkola TimurKabupaten Tapanuli Selatan Tahun 2012. Jurnal Ilmu Lingkungan 2012; 6(2): 146-160

11. WHO. Soil Transmitted Helminthiases: eliminating Soil Transmitted Helminthiases as a public health problem in children: Progress report 2001-2010 and strategic plan 2011-2020. Geneva: World Health Organization, 2012

12. Windiastuti Ike Ani, Suhartono, Nurjazuli. Hubungan Kondisi Lingkungan Rumah, Sosial Ekonomi, dan Perilaku Masyarakat dengan Kejadian Filariasis di Kecamatan Pekalongan Selatan Kota Pekalongan. Jurnal Kesehatan Lingkungan Indonesia, April 2013;12 (1): 51-57

13. Winita Rawina, Mulyati, Hendri Astuty. Upaya pemberantasan kecacingan di sekolah dasar. Makara Kesehatan, Desember 2012; 16 (2) : 65-71

14. Mudiyono, Nur Endah W, M. Sakundarno Adi. Hubungan Antara Perilaku Ibu dan Lingkungan 
Fisik Rumah dengan KejadianTuberkulosis Paru Anak di Kota Pekalongan. Jurnal Kesehatan Lingkungan Indonesia. Oktober 2015; 14(2): 45-50

15. Chadijah,S, Phetisya, P.F.S, Ni Nyoman, V. Hubungan Pengetahuan, Perilaku, dan Sanitasi Lingkungan dengan Angka Kecacingan Pada Anak
Sekolah Dasar di Kota Palu. Media Litbangkes2013;24(1): 50-56

16. Salbiah. Hubungan Karakter Siswa dan Sanitasi Lingkungan dengan Infeksi Cacingan Siswa Sekolah Dasar di Kecamatan Medan Belawan. Tesis Universitas Sumatera Utara. USU digital library. 2008 